\title{
Putative Otobius megnini-associated clinical signs in horses in South Africa (2012-2018)
}

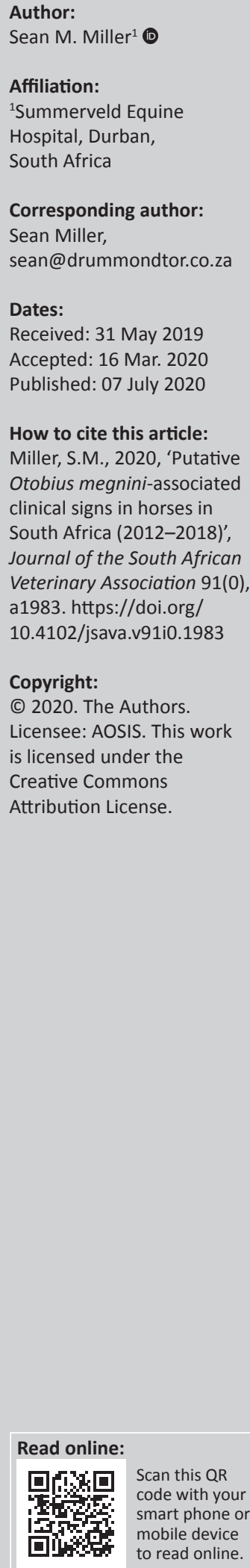

Otobius megnini has been associated with certain clinical conditions in horses in both California and Mexico. A number of cases similar to those described previously have been identified by the author in South Africa. This case report summarises these cases to demonstrate that the clinical condition occurs readily in South Africa and may be increasing in occurrence. The disease has minimal coverage in the literature making it more likely that a veterinarian, unfamiliar with the disease, will miss the diagnosis. The author would like to make veterinarians aware of this as a potential differential diagnosis. This study is a retrospective review of clinical data. Clinical records of patients with similar clinical signs and treatment were reviewed and grouped together as relevant cases for this case report. Ten cases of O. megnini associated neuromuscular dysfunction are reported, suggesting a link between the occurrence of the tick and the clinical condition. Clinical signs include third eyelid prolapse, localised muscle fasciculations, elevated heart rate and limb stamping. Serum chemistry changes commonly show increased aspartate aminotransferase and creatine kinase enzymes activities. The occurrence of the ticks within South Africa and the increasing number of cases presented demonstrate the need for more investigation into the pathophysiology of this condition.

Keywords: equine, tick, Otobius megnini, veterinary, parasitology, acarology.

\section{Introduction}

Otobius megnini-associated disease in equines has been reported by Madigan et al., showing an association of the tick and clinical disease in five horses in 1995 in California (Madigan et al. 1995:74-76), whilst Zarate-Ramos et al. (2014) described a similar case attributed to O. megnini in Mexico in 2014 (Zarate-Ramos et al. 2014:16-20). As yet, no neurotoxin has been described for this tick and it is possible that there may be neuromuscular dysfunction (Aleman 2011:481-506) alone or in relation to neurotoxin involvement (Pecina 2012:531-532). Otobius megnini is not known to transmit any pathogens (Barker \& Walker 2014).

Otobius megnini has a single host life cycle (Nava, Mangold \& Guglielmone 2009:1-5) and is parasitic for long time periods in the ear of the host (Jongejan \& Uilenberg 2004:S3-S14). Otobius megnini has a broad host range with inflammation, tissue necrosis and secondary bacterial infection the most commonly reported sequelae of infestation (Harris 1996:272-276). Otobius megnini occurs extensively throughout South Africa and can be easily transported by hosts to new locations (Nava et al. 2009:1-5; Walker et al. 2003), showing some seasonal infestation trends towards the warmer months (Nava et al. 2009:1-5). Otobius megnini undergoes multiple nymphal stages, whilst the adults are non-parasitic (Jongejan \& Uilenberg 2004:S3-S14). Nymphs and larvae can remain on the host for approximately 3 months (Broom 1920:362-363; Jongejan \& Uilenberg 2004:S3-S14). Humans and horses (Walker et al. 2003) have been reported as hosts as early as 1920. Suspected paralysis of a human patient associated with O. megnini was reported in 1958 in South Africa (Peacock 1958:201-202). In addition, a young girl suffering from O. megnini-associated otitis externa was reported in South Africa in 2001 (Naudé et al. 2001:118-119). In India, there are reports of the tick causing painful human ear infestations (Chellappa 1973:655-658). A report in Canada of euthanasia of horses because of 'demented horses' had necropsy findings that revealed large numbers of O. megnini in the ear canals with associated necrosis of the auricular and adjoining nerves. These findings implied an association of O. megnini with neurologic disease (Rich 1957:415-418). To the author's knowledge there have been no subsequent descriptions in South Africa of similarly affected equines. 
In a number of hosts, myopathy or paralysis has been associated with various tick species. Tick paralysis caused by Ixodes holocyclus is well documented in Australia, typically showing progressive lower motor neuron signs, weakness, ataxia and recumbency (Johnson 2008; Tee \& Feary 2012:181-185), causing rapid ascending paralysis (Bootes 1962:68-69) and killing foals (Bootes 1962:68-69). With I. holocyclus, a salivary toxin is implicated (GrattanSmith et al. 1997:1975-1987) with envenomation most common in small, young equids. Death is more common in the younger and smaller animal (Ruppin et al. 2012:175180). The first step in all treatments is identifying and removing the offending ticks (Grattan-Smith et al. 1997:1975-1987) as removal generally results in recovery of paralysed animals. The use of acetylpromazine to act as a calming agent and minimise muscle activity is beneficial (Tee \& Feary 2012:181-185). Treatment of I. holocyclus paralysis consists of tick antiserum and supportive care (Tee \& Feary 2012:181-185). In North America, a neurotoxin secreted by engorged female Dermacentor andersoni or Dermacentor variabilis (Krishnan et al. 2009:358-362) causes similar signs.

A further differential diagnosis for this clinical condition includes myotonia where abnormal muscle contractions are seen, particularly in response to a stimulus (Cassart, Coignoul \& Desmecht 2008:1-16). For example, congenital myotonia has been described where skeletal muscles have sustained contractions (Jamison et al. 1987:353-358). Toxic myopathies (monensin poisoning) may also display muscle tremors, 'colic' signs, tachycardia, tachypnoea with increases in serum levels of aspartate aminotransferase (AST) and creatine kinase (CK) enzyme activity (Harris 1996:272-276), whilst seasonal pasture myopathy affects respiratory and scapular muscles and is caused by ingestion of a toxin (Finno et al. 2006:1134-1141). Exertional rhabdomyolysis may also present with muscle tremors, tachycardia, tachypnoea and increases in serum levels of AST and CK enzyme activity.

A number of cases, similar to those described by Madigan (1995:74-76) and Zarate-Ramos et al. (2014:16-20), have been identified by the author in KwaZulu-Natal, South Africa. This case report summarises these cases to demonstrate that this is a clinical condition that occurs readily in this region. The increase in prevalence would indicate a need for more investigation into the pathophysiology of this condition.

\section{Materials and methods}

Clinical records of patients with similar presenting clinical signs and treatment were reviewed. Cases were excluded if they did not have serum chemistry data, positive identification of the presence of O. megnini, third eyelid prolapse and muscle fasciculations. In all cases except one, blood samples were taken at the time of first clinical examination. All selected cases were Thoroughbred racehorses in the pre-training phase of their career that had recently arrived at one of two race training centres in KwaZulu-Natal, South Africa. Presentation was generally 2 weeks after arriving at the race training centres, either from yearling sales or from pre-training farms. As such, all horses were only in light work. None of the histories related any of the signs to work, or immediately post-work. The cases were tabulated to compare similarities.

\section{Patient presentation, management and outcome}

The clinical findings and treatments are reported in Table 1, and the haematological and serum chemistry findings are reported in Table 2. Most commonly affected individuals were 2-year-old (eight out of 10) fillies (nine out of 10) and horses that had recently moved yards. The most common presenting complaints were stamping of hooves, muscle fasciculations and third eyelid prolapse. Less commonly seen signs included yawning, head tilting, circling and recumbency. In all cases, O. megnini ticks were identified and removed from the ears. Occurrence of this disease seems to cluster around February to May and September to October with the greatest number of cases occurring in May (three out of 10) and September (three out of 10) during spring and autumn, which may be associated with warmer months in the Southern hemisphere.

In seven out of 10 cases AST and 10 out of 10 cases CK levels were raised. In case 9, AST and CK were only measured 4 days after the clinical signs first presented. The AST for this case was in the normal range and the CK mildly elevated. It is therefore difficult to associate these levels with the clinical condition. In the other two cases with normal AST values, the CK levels were both high (cases 8 and 10). The assumption would be that sampling occurred at a more acute phase where CK level was elevated, but AST was yet to be elevated. Serum CK peaks after muscle injury at approximately $4 \mathrm{~h}-6 \mathrm{~h}$ and has a half-life of $6 \mathrm{~h}-10 \mathrm{~h}$, whilst AST has a much slower peak of $24 \mathrm{~h}-48 \mathrm{~h}$ and a halflife of between 2 and 10 days (Cardinet, Littrell \& Freedland 1967:219-226; Valberg et al. 1993:11-16; Valentine 2003: 250-252). The mean AST for these cases was $1423.92 \mathrm{U} / \mathrm{L}$ (standard deviation $[\mathrm{SD}]=852.31$; range 335-2985). The mean CK for these cases was 1833.77 U/L (SD = 1133.54; range 515-4072). Note that not all readings had an absolute measurement and where this is the case the highest value recorded was taken as the value for the estimation of mean.

Cases 1 and 10 had mild neutrophilia accompanied by a mild lymphopaenia (case 1 had a lymphopaenia without neutrophilia on a follow up haematology). Case 6 had a mild lymphopaenia without a neutrophilia. On the followup examination, case 1 also had a basophilia, and cases 2 , $3,4,9$ and 10 had a basophilia. These may be endogenous corticosteroid-related stress response leukograms. Alternatively, the neutrophilia may be because of physical damage of the ear caused by the ticks within the ear. Cases 
TABLE 1: Clinical findings and treatment of the reported cases.

\begin{tabular}{|c|c|c|c|c|c|c|c|}
\hline Case no. & Date & Gender & $\begin{array}{c}\text { Age } \\
\text { (years) }\end{array}$ & Presenting signs and history & $\begin{array}{l}\text { Otobius megnini } \\
\text { identified }\end{array}$ & Treatment & Duration/outcome \\
\hline \multirow[t]{2}{*}{1} & 09 May 2012 & \multirow[t]{2}{*}{ Filly } & \multirow[t]{2}{*}{2} & $\begin{array}{l}\text { Heart rate: } 48 \mathrm{bpm} \text {, cramping of legs, } \\
\text { stamping of feet, intermittent third eyelid } \\
\text { prolapse and muscle fasciculations. } \\
\text { Recently moved to racing yard }\end{array}$ & \multirow[t]{2}{*}{$\begin{array}{l}\text { Multiple in both } \\
\text { ears }\end{array}$} & $\begin{array}{l}\text { Dexamethasone (Colvasone } \S \text { ) } \\
0.08 \mathrm{mg} / \mathrm{kg} \text { IV, butylscopolamine } \\
\text { bromide (Buscopan compositum } \mid \text { ) and } \\
\text { phenylbutazone (Pheynlbutazone } \dagger \text { ) } \\
4.4 \mathrm{mg} / \mathrm{kg} \text { IV }\end{array}$ & 10 days \\
\hline & 10 May 2012 & & & Heart rate: $40 \mathrm{bpm}$ & & $\begin{array}{l}\text { Acepromazine (Neurotranq } \dagger \text { ) } \\
0.04 \mathrm{mg} / \mathrm{kg} \text { IV and doramectin } \\
\text { (Dectomax } \$ \text { ) } 0.18 \mathrm{mg} / \mathrm{kg} \mathrm{IM}\end{array}$ & Recovered \\
\hline 2 & $\begin{array}{l}13 \\
\text { September } \\
2013\end{array}$ & Filly & 2 & $\begin{array}{l}\text { Constant third eyelid prolapse on exam. } \\
\text { Muscle fasciculations. Continuous yawning. } \\
\text { Recently moved to racing yard }\end{array}$ & $\begin{array}{l}\text { Multiple in both } \\
\text { ears }\end{array}$ & $\begin{array}{l}\text { Acepromazine (Neurotranq } \dagger \text { ) } \\
0.04 \mathrm{mg} / \mathrm{kg} \mathrm{IV} \text {, ivermectin (Solution LA } \\
3.5 \% \dagger \dagger \text { ) } 450 \mu \mathrm{g} / \mathrm{kg} \mathrm{SC} \text { and phenylbutazone } \\
\text { (Pheynlbutazone } \dagger \text { ) } 4.4 \mathrm{mg} / \mathrm{kg} \mathrm{IV}\end{array}$ & $\begin{array}{l}2 \text { Days } \\
\text { Recovered }\end{array}$ \\
\hline 3 & $\begin{array}{l}21 \text { October } \\
2014\end{array}$ & Filly & 2 & $\begin{array}{l}\text { Marked third eyelid prolapse bilaterally, } \\
\text { triceps muscle fasciculations, stamping of } \\
\text { both front hooves and heart rate } 48 \mathrm{bpm} \text {. } \\
\text { Recently moved to racing yard }\end{array}$ & $\begin{array}{l}\text { Multiple in both } \\
\text { ears }\end{array}$ & $\begin{array}{l}\text { Acepromazine (Neurotranq } \dagger \text { ) } \\
0.04 \mathrm{mg} / \mathrm{kg} \text { IV and dexamethasone } \\
\text { (Colvasone } \$ \text { ) } 0.08 \mathrm{mg} / \mathrm{kg} \text { IV }\end{array}$ & $\begin{array}{l}3 \text { days } \\
\text { Recovered }\end{array}$ \\
\hline 4 & $\begin{array}{l}17 \\
\text { September } \\
2015\end{array}$ & Filly & 2 & $\begin{array}{l}\text { Constant third eyelid prolapse of the right } \\
\text { eye. Stamping of hooves. Unsettled. } \\
\text { Recently moved to racing yard }\end{array}$ & $\begin{array}{l}\text { Multiple in both } \\
\text { ears }\end{array}$ & $\begin{array}{l}\text { Acepromazine (Neurotranq } \dagger \text { ) } \\
0.04 \mathrm{mg} / \mathrm{kg} \text { IV }\end{array}$ & $\begin{array}{l}1 \text { day } \\
\text { Recovered }\end{array}$ \\
\hline 5 & $\begin{array}{l}\text { 07 March } \\
2016\end{array}$ & Filly & 2 & $\begin{array}{l}\text { Heart rate } 52 \mathrm{bpm} \text {, constant left eye third } \\
\text { eyelid prolapse, generalised muscular } \\
\text { fasciculations of trunk and thorax and } \\
\text { recumbent in the stable. Recently moved } \\
\text { to racing yard }\end{array}$ & $\begin{array}{l}\text { Multiple in both } \\
\text { ears }\end{array}$ & $\begin{array}{l}\text { Acepromazine (Neurotranq } \dagger \text { ) } \\
0.04 \mathrm{mg} / \mathrm{kg} \text { IV and ketoprofen } \\
\text { (Ketofen }+ \text { ) } 2.2 \mathrm{mg} / \mathrm{kg} \text { IV }\end{array}$ & $\begin{array}{l}2 \text { days } \\
\text { Recovered }\end{array}$ \\
\hline 6 & 09 May 2016 & Filly & 2 & $\begin{array}{l}\text { Single limb stamping and chopping } \\
\text { associated with muscle fasciculations on } \\
\text { the ipsilateral lateral thorax Recently } \\
\text { moved to racing yard }\end{array}$ & $\begin{array}{l}\text { Multiple in both } \\
\text { ears }\end{array}$ & $\begin{array}{l}\text { Flunixin meglumine (Pyroflam§) } \\
1.1 \mathrm{mg} / \mathrm{kg} \mathrm{IV}\end{array}$ & $\begin{array}{l}1 \text { day } \\
\text { Recovered }\end{array}$ \\
\hline 7 & 13 May 2016 & Filly & 2 & $\begin{array}{l}\text { Stamping of hooves, chopping with front } \\
\text { limbs and intermittent third eyelid prolapse } \\
\text { mainly affecting the right eye. Recently } \\
\text { arrived in racing yard }\end{array}$ & $\begin{array}{l}\text { Multiple in both } \\
\text { ears }\end{array}$ & $\begin{array}{l}\text { Ketoprofen (Ketofen }+\ddagger) 2.2 \mathrm{mg} / \mathrm{kg} \text { IV, } \\
\text { acepromazine (Neurotranq }{ }^{\dagger} \text { ) } \\
0.04 \mathrm{mg} / \mathrm{kg} \text { IV and ivermectin (Solution } \\
\text { LA } 3.5 \% \dagger^{+} 450 \mu \mathrm{g} / \mathrm{kg} \mathrm{SC}\end{array}$ & $\begin{array}{l}\text { 1day } \\
\text { Recovered }\end{array}$ \\
\hline 8 & $\begin{array}{l}05 \text { February } \\
2017\end{array}$ & Colt & 1.5 & $\begin{array}{l}\text { Unilateral lower abdominal wall } \\
\text { fasciculations and occasional recumbency } \\
\text { with seizure-like paddling of hooves. } \\
\text { Recently moved to racing yard }\end{array}$ & $\begin{array}{l}\text { Multiple in both } \\
\text { ears }\end{array}$ & 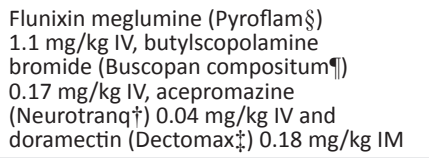 & $\begin{array}{l}1 \text { day } \\
\text { Recovered }\end{array}$ \\
\hline 9 & 02 April 2017 & Filly & 1.5 & $\begin{array}{l}\text { Constant left third eyelid prolapse and } \\
\text { muscle fasciculations of the right flank. } \\
\text { Recently moved to racing yard }\end{array}$ & $\begin{array}{l}\text { Multiple in both } \\
\text { ears }\end{array}$ & $\begin{array}{l}\text { Flunixin meglumine (Pyroflam } \S \text { ) } \\
1.1 \mathrm{mg} / \mathrm{kg} \text { IV and dexamethasone } \\
\text { (Colvasone } \$ \text { ) } 0.08 \mathrm{mg} / \mathrm{kg} \text { IV }\end{array}$ & $\begin{array}{l}1 \text { day } \\
\text { Recovered }\end{array}$ \\
\hline 10 & $\begin{array}{l}16 \text { October } \\
2018\end{array}$ & Filly & 2 & $\begin{array}{l}\text { Stamping of hooves, chopping front feet } \\
\text { and muscle fasciculations of triceps and } \\
\text { hindquarters. Intermittent recumbency. } \\
\text { Mild third eyelid prolapse with noise } \\
\text { stimulation }\end{array}$ & $\begin{array}{l}\text { Multiple in both } \\
\text { ears }\end{array}$ & $\begin{array}{l}\text { Acepromazine (Neurotranq } \dagger \text { ) } \\
0.04 \mathrm{mg} / \mathrm{kg} \text { IV, flunixin meglumine } \\
\text { (Pyroflam } \$ \text { ) } 1.1 \mathrm{mg} / \mathrm{kg} \text { IV }\end{array}$ & $\begin{array}{l}3 \text { days } \\
\text { Recovered }\end{array}$ \\
\hline
\end{tabular}

bpm, beats per minute; IV, intravenous, IM, intramuscular; SC, sub cutaneous.

$\dagger$, Virbac, Fort Worth Texas, United States; $\$$, Zoetis, Parsippany-Troy Hills, New Jersey, United States; §, Norbrook, Newry, Northern Ireland; $\uparrow$, Boehringer Ingelheim, Ingelheim am Rhein, Germany; $\dagger$, MSD Animal Health, Johannesburg, South Africa; $+\$$, Merial, Johannesburg, South Africa

3, 8 and 9 had mild decreased mean corpuscular volume (MCV), and cases 3, 5, 8 and 9 had mildly elevated red cell distribution width (RDW). The microcytosis may be an artefact caused by delayed processing of blood samples leading to cell swelling, or may be because of the younger animals having a physiological normally lower MCV. The increases in RDW without other haematological changes related to anaemia may be because of fragmentation of cells during collection or agglutination (Satué, Hernández \& Muñoz 2012:573-596). Case 1 had mild low total protein on two examinations and elevated creatinine on three examinations, and elevated urea on one examination. Because of the nature of a retrospective study, full serum chemistry data were not available for cases 2, 3, 5 and 7 . Because of the strong suspicion of the clinical condition at the time of treatment, full serum chemistry was not run; AST and CK were run to confirm that they were elevated. In the third and fourth follow-up clinical pathology of case 1, no haematology was performed and only previously elevated serum chemistry was re-evaluated. The mean time to recovery was 2.5 days $(\mathrm{SD}=2.62)$.
These 10 cases were documented over a 6-year period. A number of similar cases occurred during this period but because of poor record keeping and clients' lack of knowledge of the disease, a number of cases were treated without the author's knowledge or without accurate enough records to verify the cases retrospectively.

Mechanical removal of ticks is essential to alleviate the signs in the author's experience. Treatment with acetylpromazine (Neurotranq $\left.{ }^{1}\right) 0.04 \mathrm{mg} / \mathrm{kg}$ and flunixin meglumine (Pyroflam ${ }^{2}$ ) $1.1 \mathrm{mg} / \mathrm{kg}$ as well as an ivermectin-type parasiticide are the first choice of medical treatments that are effective in the author's experience. The use of non-steroidal antiinflammatories and acetylpromazine is sometimes required for several days after diagnosis to treat on-going signs.

\section{Limitations}

The small number of cases, some of which did not have complete serum chemistry data, was a limitation of 1.Norbrook, Newry, Northern Ireland

2.Virbac, Fort Worth Texas, United States 
this study. The lack of consistent clinical signs is also another limiting factor.

\section{Discussion}

The occurrence of this condition has, as far as the author is aware, not been previously described in South Africa. Whilst few cases have been documented, the occurrence of the condition warrants further investigation. Seasonal peaks in larval stages in warmer months seem to coincide with the incidence of cases in this study (Diyes \& Rajakaruna 2016:170-175).

It is unlikely that the condition, although occurring mainly in fillies, is related to exertional rhabdomyolysis because none of the histories reported excessive work or immediately postwork. The horses in this study were all new to their yards and were not under excessive training loads according to their trainers. However, this cannot be entirely ruled out in this study: muscle biopsies were not taken but would be useful for future studies. Testing for other myopathies was not performed.

The exact pathophysiology of this condition is not clear. Other tick toxicoses frequently result in paralysis, but ticks may also cause other hypersensitivity and immunological reactions (Mans, Gothe \& Neitz 2008) with approximately 69 tick species causing some form of paralysis worldwide (Mans et al. 2008). Paralysis caused by soft ticks is associated with the prolonged feeding pattern of larvae and nymphs (Mans et al. 2008). In most species causing paralysis, this occurs in the engorgement phase where numerous protein products are produced by the salivary glands of the tick which affect the nervous system (Mans et al. 2008). However, it is not reported that O. megnini produces any toxin/s which could cause the neuromuscular dysfunction seen in these cases or whether its location within the ears may cause inflammatory reactions that cause neurological signs. The signs associated with these cases are also not consistent with those of other known paralysis ticks (Madigan et al. 1995: 74-76; Rich 1957:415-418). There are indications that increased motor unit activity could be the cause of the signs seen in these cases (Madigan et al. 1995:74-76; Mans, Gothe \& Neitz 2004:S95-S111). There is also potential malfunctioning of ion channels that may play a role in the pathophysiology of the condition (Cassart et al. 2008:1-16). Aleman suggests that O. megnini causes a myotonia by altering neuromuscular transmission at the postsynaptic membrane of the neuromuscular junction (Aleman 2011:481-506). Whether the condition is a true paralysis or a myotonia remains to be shown. It is clear to the author that there is some neuromuscular dysfunction and myotonia is more likely to be occurring which suggests that 'O. megnini-associated neuromuscular dysfunction' may be a more appropriate description of the condition based on the current limited knowledge.

Otobius megnini is well established in the local racehorse training centres and seems to be present on a large number of equines in the population. The occurrence of the condition in young horses that are relatively new to the stable yard suggests that there may be an element of immune suppression that allows the condition to occur in the new, presumably stressed, individual horses. Alternatively, there may also be a level of immunity that develops against the condition as older horses in the same yard are exposed to the same ticks but do not seem to succumb to clinical disease. A lack of immunity in naive horses may also explain their increased susceptibility on arrival in a new environment. There is evidence that Thoroughbreds may be more susceptible than crossbreds to infestation and that this may be related to the development of immunity (Diyes \& Rajakaruna 2017:164-176; Wikel 1996: 1-22). In addition, well-groomed horses, with shaved ears seemed to be more susceptible to infestation (Diyes \& Rajakaruna 2016:170-175), although regular cleaning of shaved ears may allow frequent identification and removal of ticks.

Veterinarians should remain vigilant for this condition and ensure horse owners are informed about tick removal (Pecina 2012:531-532) and appropriate application of locally available parasiticides (Drummond 1985:111-119) as part of a holistic approach to the control of tick infestations. The condition in this study has been shown to occur in South Africa and,

TABLE 2: Haematological and serum chemistry findings for each case reported.

\begin{tabular}{|c|c|c|c|c|c|c|c|c|c|c|c|}
\hline \multirow{2}{*}{$\begin{array}{l}\text { Case } \\
\text { no. }\end{array}$} & \multirow{2}{*}{ Date } & \multicolumn{10}{|c|}{ Haematological and serum chemistry abnormalities } \\
\hline & & $\begin{array}{c}\text { Red blood cells } \\
\left(6.80 \times 10^{12} / \mathrm{L}\right. \\
\left.-12.90 \times 10^{12} / L\right)\end{array}$ & $\begin{array}{c}\text { Haematocrit } \\
(32 \%-53 \%)\end{array}$ & $\begin{array}{c}\text { Haemoglobin } \\
(11.0 \mathrm{~g} / \mathrm{L}- \\
19.0 \mathrm{~g} / \mathrm{L})\end{array}$ & $\begin{array}{c}\text { Mean } \\
\text { corpuscular } \\
\text { volume } \\
\text { (37 fL- } \\
59 \mathrm{fL})\end{array}$ & $\begin{array}{c}\text { Mean } \\
\text { corpuscular } \\
\text { haemoglobin } \\
\text { (12.3 pg- } \\
19.9 \mathrm{pg})\end{array}$ & $\begin{array}{l}\text { Mean corpuscular } \\
\text { haemoglobin } \\
\text { concentration } \\
\text { (31.0 g/dL- } \\
45 \mathrm{~g} / \mathrm{dL})\end{array}$ & $\begin{array}{c}\text { Red cell } \\
\text { distribution } \\
\text { width } \\
(17.00 \%- \\
25.4 \%)\end{array}$ & $\begin{array}{c}\text { White blood } \\
\text { cells } \\
(5.40 \times \\
10^{9} / \mathrm{L}- \\
\left.14.30 \times 10^{9} / \mathrm{L}\right)\end{array}$ & $\begin{array}{c}\text { Neutrophils } \\
2.26 \times 10^{9} / \mathrm{L}- \\
\left.8.5 \times 10^{9} / \mathrm{L}\right)\end{array}$ & $\begin{array}{l}\text { Lymphocytes } \\
\left(1.5 \times 10^{9} / \mathrm{L}-\right. \\
\left.7.7 \times 10^{9} / \mathrm{L}\right)\end{array}$ \\
\hline \multirow[t]{3}{*}{1} & 10 May 2012 & 9.76 & 37.8 & 13.5 & 38.8 & 13.8 & 35.7 & 23 & 11.24 & 10.00 & 0.45 \\
\hline & 16 May 2012 & 10.85 & 41.2 & 15.0 & 37.9 & 13.8 & 36.4 & 22.7 & 7.82 & 5.96 & 1.04 \\
\hline & 17 May 2012 & - & - & - & - & - & - & - & - & - & - \\
\hline 2 & 13 Sept. 2013 & 8.83 & 37.7 & 14.2 & 42.6 & 16.1 & 37.8 & 21.4 & 8.84 & 5.26 & 2,76 \\
\hline 3 & 21 October 2014 & 11.84 & 42.95 & 16.6 & 36 & 14.1 & 38.8 & 25.6 & 11.00 & 5.55 & 4.92 \\
\hline 4 & 17 September 2015 & 9.89 & 38.10 & 13.7 & 39 & 13.8 & 35.8 & 24.9 & 9.29 & 6.49 & 1.91 \\
\hline 5 & 07 March 2016 & 10.33 & 39.25 & 14.4 & 38 & 14.0 & 36.8 & 25.7 & 10.71 & 6.09 & 3.80 \\
\hline 6 & 09 May 2016 & 8.61 & 34.81 & 12 & 40 & 14.0 & 34.5 & 24.2 & 6.94 & 5.08 & 1.32 \\
\hline 7 & 13 May 2016 & 9.87 & 38.90 & 14.6 & 39 & 14.8 & 37.6 & 24.4 & 9.81 & 6.34 & 2.95 \\
\hline 8 & 05 February 2017 & 10.32 & 31.16 & 12.8 & 30 & 12.4 & 41.0 & 27.6 & 11.74 & 6.88 & 4.21 \\
\hline 10 & 16 Oct. 2018 & 7.86 & 34.30 & 12.1 & 43.6 & 15.4 & 35.3 & 21.9 & 11.58 & 9.39 & 1.41 \\
\hline
\end{tabular}

Note: Abnormal values in bold type. 
TABLE 2 (Continues...): Haematological and serum chemistry findings for each case reported.

\begin{tabular}{|c|c|c|c|c|c|c|c|c|c|c|c|c|c|}
\hline \multirow{2}{*}{$\begin{array}{l}\text { Case } \\
\text { no. }\end{array}$} & \multirow{2}{*}{ Date } & \multicolumn{12}{|c|}{ Haematological and serum chemistry abnormalities } \\
\hline & & $\begin{array}{c}\text { Monocytes } \\
\left(0.10 \times 10^{9} / \mathrm{L}\right. \\
\left.-1.00 \times 10^{9} / \mathrm{L}\right)\end{array}$ & $\begin{array}{c}\text { Eosinophils } \\
\left(0.00 \times 10^{9} / \mathrm{L}\right. \\
\left.-1.00 \times 10^{9} / \mathrm{L}\right)\end{array}$ & $\begin{array}{c}\text { Basophils } \\
\left(0.00 \times 10^{9} / \mathrm{L}\right. \\
\left.-0.03 \times 10^{9} / \mathrm{L}\right)\end{array}$ & $\begin{array}{c}\text { Creatinine } \\
(71 \mu \mathrm{mol} \\
-194 \mu \mathrm{mol} / \mathrm{L})\end{array}$ & $\begin{array}{c}\text { Blood } \\
\text { urea } \\
\text { nitrogen } \\
(3.6 \mathrm{mmol} / \\
\mathrm{L}-8.9 \\
\mathrm{mmol} / \mathrm{L})\end{array}$ & $\begin{array}{c}\text { Total protein } \\
\text { (56 g/L - } \\
79 \mathrm{~g} / \mathrm{L})\end{array}$ & $\begin{array}{l}\text { Albumin } \\
(19 \mathrm{~g} / \mathrm{L}- \\
32 \mathrm{~g} / \mathrm{L})\end{array}$ & $\begin{array}{c}\text { Globulin } \\
(24 \mathrm{~g} / \mathrm{L}- \\
47 \mathrm{~g} / \mathrm{L})\end{array}$ & $\begin{array}{c}\text { Aspartate } \\
\text { aminotransferase } \\
(100 \mathrm{U} / \mathrm{L}- \\
600 \mathrm{U} / \mathrm{L})\end{array}$ & $\begin{array}{c}\text { Gamma- } \\
\text { glutamyl } \\
\text { transferase } \\
(0 \mathrm{U} / \mathrm{L}- \\
87 \mathrm{U} / \mathrm{L})\end{array}$ & $\begin{array}{c}\text { Total } \\
\text { Bilirubin } \\
\text { (0 U/L-60 } \\
\text { U/L) }\end{array}$ & $\begin{array}{c}\text { Creatine } \\
\text { kinase } \\
(10 \mathrm{U} / \mathrm{L} \\
-350 \mathrm{U} / \mathrm{L})\end{array}$ \\
\hline \multirow[t]{3}{*}{1} & 10 May 2012 & 0.54 & 0.23 & 0.02 & 118 & 4.5 & 55 & 28 & 27 & $>600$ & 18 & 43 & $>2035$ \\
\hline & 16 May 2012 & 0.60 & 0.18 & 0.04 & 211 & 9.6 & 53 & 26 & 26 & 2466 & 12 & 32 & 1838 \\
\hline & 17 May 2012 & - & - & - & 262 & 5.4 & - & - & - & 2985 & - & - & 994 \\
\hline 2 & 13 Sept. 2013 & 0.51 & 0.26 & 0.05 & - & - & - & - & - & 934 & - & - & 1783 \\
\hline 3 & 21 October 2014 & 0.05 & 0.42 & 0.07 & - & - & - & - & - & 1908 & - & - & $>2036$ \\
\hline 4 & 17 September 2015 & 0.32 & 0.53 & 0.04 & 137 & 5.1 & 61 & 25 & 36 & 1788 & 29 & 29 & 4005 \\
\hline 5 & 07 March 2016 & 0.55 & 0.24 & 0.03 & - & - & - & - & - & 718 & - & - & 564 \\
\hline 6 & 09 May 2016 & 0.33 & 0.18 & 0.02 & 97 & 6.1 & 61 & 29 & 32 & 1408 & 23 & 5 & $>2036$ \\
\hline 7 & 13 May 2016 & 0.43 & 0.08 & 0.01 & - & - & - & - & - & 1995 & - & - & $>4072$ \\
\hline 8 & 05 February 2017 & 0.27 & 0.35 & 0.03 & 97 & 5.4 & 63 & 31 & 31 & 335 & 25 & 32 & 659 \\
\hline 10 & 16 Oct. 2018 & 0.48 & 0.26 & 0.04 & 159 & 6.8 & 62 & 28 & 35 & 559 & 75 & 41 & 2473 \\
\hline
\end{tabular}

Note: Abnormal values in bold type.

whilst simple to treat, veterinarians not familiar with it may misdiagnose the signs and treat incorrectly resulting in unnecessary morbidity and mortality of animals.

Future study is needed to determine if there is a toxic or physical cause to the condition and the true prevalence of both the ticks and the condition within the racing Thoroughbred population of South Africa.

\section{Acknowledgements}

The author would like to acknowledge Prof. Banie Penzhorn, Prof. Ann Carstens and Mr Philip Norton for their advice and help in the editing of the manuscript.

\section{Competing interests}

The author declares that he has no financial or personal relationships that may have inappropriately influenced him in writing this article.

\section{Author's contributions}

S.M. was responsible for literature review, collation, writing and editing of the case report.

\section{Ethical consideration}

The retrospective data used in this study was obtained from clinical cases presented for diagnosis and treatment by a registered veterinarian.

\section{Funding information}

This research received no specific grant from any funding agency in the public, commercial, or not-for-profit sectors.

\section{Data availability statement}

Data sharing is not applicable to this article as no new data were created or analysed in this study.

\section{Disclaimer}

The views and opinions expressed in this article are those of the author and not the institution he works for.

\section{References}

Aleman, M., 2011, 'Miscellaneous neurologic or neuromuscular disorders in horses', Veterinary Clinics of North America: Equine Practice 27(3), 481-506. https://doi. org/10.1016/j.cveq.2011.08.001

Barker, S.C. \& Walker, A.R., 2014, 'Ticks of Australia: The species that infest domestic animals and humans', Zootaxa 3816(1), 1-144. https://doi.org/10.11646/ zootaxa.3816.1.1

Bootes, B.W., 1962, 'A fatal paralysis in foals from Ixodes holocyclus Neumann infestation', Australian Veterinary Journal 38(2), 68-69. https://doi.org/10.1111/ j.1751-0813.1962.tb08725.x

Broom, R., 1920, 'Note on the spinose ear tick (Ornithodorus megnini Dugès) in the human ear in South Africa', The Journal of Laryngology, Rhinology, and Otology 35(12), 362-363. https://doi.org/10.1017/S1755146300021442

Cardinet, G.H., Littrell, J.F. \& Freedland, R.A., 1967, 'Comparative investigations of serum creatine phosphokinase and glutamic-oxaloacetic transaminase activities in equine paralytic myoglobinuria', Research in Veterinary Science 8(2), 219-226. https://doi.org/10.1016/S0034-5288(18)34639-3

Cassart, D., Coignoul, F. \& Desmecht, D., 2008, 'Morphopathologic review of myopathies among equidae: Revue morphopathologique des myopathies equines', Annales de Medecine Veterinaire 152, 1-16.

Chellappa, D.J., 1973, 'Note on spinose ear tick infestation in man and domestic animals in India and its control', Madras Agricultural Journal 60, 655-658.

Diyes, G.C.P. \& Rajakaruna, R.S., 2016, 'Seasonal dynamics of spinose ear tick Otobius megnini associated with horse otoacariasis in Sri Lanka', Acta Tropica 159, 170-175. https://doi.org/10.1016/j.actatropica.2016.03.025

Diyes, G.C.P. \& Rajakaruna, R.S., 2017, 'Life cycle of spinose ear tick, Otobius megnin (Acari: Argasidae) infesting the race horses in Nuwara Eliya, Sri Lanka', Acta Tropica 166, 164-176. https://doi.org/10.1016/j.actatropica.2016.11.026

Drummond, R.O., 1985, 'New methods of applying drugs for the control of ectoparasites', Veterinary Parasitology 18(2), 111-119. https://doi.org/10.1016/ 0304-4017(85)90061-5

Finno, C.J., Valberg, S.J., Wunschmann, A. \& Murphy, M.J., 2006, 'Seasonal pasture myopathy in horses in the midwestern United States: 14 cases (1998-2005)', Journal of the American Veterinary Medical Association 229(7), 1134-1141. https://doi.org/10.2460/javma.229.7.1134

Grattan-Smith, P.J., Morris, J.G., Johnston, H.M., Yiannikas, C., Malik, R., Russell, R. et al., 1997, "Clinical and neurophysiological features of tick paralysis', Brain 120(11), 1975-1987. https://doi.org/10.1093/brain/120.11.1975

Harris, P., 1996, 'Differential diagnosis of an acute episode of a primary myopathy out at pasture', Equine Veterinary Education 8(5), 272-276. https://doi.org/10.1111/ j.2042-3292.1996.tb01702.x

Jamison, J.M., Baird, J.D., Smith-Maxie, L.L. \& Hulland, T.J., 1987, 'A congenital form of myotonia with dystrophic changes in a quarterhorse', Equine Veterinary Journal 19(4), 353-358. https://doi.org/10.1111/j.2042-3306.1987.tb01433.x

Johnson, A.L., 2008, 'Differential diagnosis of muscle tremor and paresis', in M. Furr \& S. Reed (eds.), Equine neurology, p. 149, Blackwell Publishing, Oxford.

Jongejan, F. \& Uilenberg, G., 2004, 'The global importance of ticks', Parasitology 129(1), S3-S14. https://doi.org/10.1017/S0031182004005967

Krishnan, A.V., Lin, C.S., Reddel, S.W., Mcgrath, R. \& Kiernan, M.C., 2009, 'Conduction block and impaired axonal function in tick paralysis', Muscle Nerve 40(3), 358-362. https://doi.org/10.1002/mus.21395 
Madigan, J.E., Valberg, S.J., Ragle, C. \& Moody, J.L., 1995, 'Muscle spasms associated with ear tick (Otobius megnini) infestations in five horses', Journal of the American Veterinary Medical Association 207(1), 74-76.

Mans, B.J., Gothe, R. \& Neitz, A.W.H., 2004, 'Biochemical perspectives on paralysis and other forms of toxicoses caused by ticks', Parasitology 129(s1), S95-S111. https:// doi.org/10.1017/S0031182003004670

Mans, B.J., Gothe, R. \& Neitz, A.W.H., 2008, 'Tick toxicosis: Perspectives on paralysis and other forms of toxicosis caused by ticks', in A.S. Bowman \& P.A. Nuttall (eds.) Ticks: Biology, disease and control, pp. 108-126, Cambridge University Press, Cambridge.

Naudé, T.W., Heyne, H., Van der Merwe, I.R. \& Benic, M.J., 2001, 'Spinose ear tick, Otobius megnini (Dugès, 1884) as the cause of an incident of painful otitis externa in humans', Journal of the South African Veterinary Association 72(3), 118-119. https://doi.org/10.4102/jsava.v72i3.633

Nava, S., Mangold, A.J. \& Guglielmone, A.A., 2009, 'Field and laboratory studies in a neotropical population of the spinose ear tick, Otobius megnini', Medical and VeterinaryEntomology23(1),1-5.https://doi.org/10.1111/j.1365-2915.2008.00761.x

Peacock, P.B., 1958, 'Tick paralysis or poliomyelitis', South African Medical Journal 32(8), 201-202.

Pecina, C.A., 2012, 'Tick paralysis', Seminars Neurology 32(5), 531-532. https://doi.org/ $10.1055 / \mathrm{s}-0033-1334474$

Rich, G.B., 1957, 'The ear tick, Otobius megnini (Duges), (Acarina: Argasidae), and its record in British Columbia', Canadian Journal of Comparative Medicine and Veterinary Science 21(12), 415-418.
Ruppin, M., Sullivan, S., Condon, F., Perkins, N., Lee, L., Jeffcott, L.B. et al., 2012 'Retrospective study of 103 presumed cases of tick (Ixodes holocyclus) envenomation in the horse', Australian Veterinary Journal 90(5), 175-180. https:// doi.org/10.1111/j.1751-0813.2012.00916.x

Satué, K., Hernández, A. \& Muñoz, A., 2012, 'Physiological factors in the interpretation of equine haematological profile', in C. Lawrie (ed.), Hematology - Science and practice, pp. 573-596, Intech Open Science, Croatia.

Tee, S.Y. \& Feary, D.J., 2012, 'Suspected tick paralysis (Ixodes holocyclus) in a miniature horse', Australian Veterinary Journal 90(5), 181-185. https://doi.org/10.1111/ j.1751-0813.2012.00909.x

Valberg, S., Jonsson, L., Lindholm, A. \& Holmgren, N., 1993, 'Muscle histopathology and plasma aspartate aminotransferase, creatine kinase and myoglobin changes with exercise in horses with recurrent exertional rhabdomyolysis', Equine Veterinary Journal 25(1), 11-16. https://doi.org/10.1111/j.2042-3306.1993.tb02893.x

Valentine, B.A., 2003, 'Serum CK and AST in equine neuromuscular disease: Searching for diagnostic approaches', Equine Veterinary Education 15(5), 250-252. https:// doi.org/10.1111/j.2042-3292.2003.tb00536.x

Walker, A.R., Bouattour, A., Camicas, J.-L., Estrada-Pena, A., Horak, I.G., Latif, A.A. et al., 2003, Ticks of domestic animals in Africa: A guide to identification of species, Bioscience Reports, Edinburgh.

Wikel, S.K., 1996, 'Host immunity to ticks', Annual Review of Entomology 41, 1-22. https://doi.org/10.1146/annurev.en.41.010196.000245

Zarate-Ramos, J.J., Nevarez-Garza, A.M., Zamora-Avila, D.E. \& Rodriguez-Tovar, L.E., 2014, 'Myotonia and colic associated with the spinose ear tick, Otobius megnin , in a horse in Northern Mexico', Research Journal of Parasitology 9(1), 16-20. https://doi.org/10.3923/jp.2014.16.20 